Revue bibliographique pour le domaine irano-aryen

\title{
Na'ama O. Arom. “Arrowheads of Hülegü Khan : Envoys and Diplomacy in His Invasion of the Middle East, 1255-1262"
}

\section{Simon Berger}

\section{(2) OpenEdition}

Journals

Édition électronique

URL : https://journals.openedition.org/abstractairanica/53889

DOI : 10.4000/abstractairanica.53889

ISSN : 1961-960X

Éditeur :

CNRS (UMR 7528 Mondes iraniens et indiens), Éditions de l'IFRI

\section{Référence électronique}

Simon Berger, " Na'ama O. Arom. "Arrowheads of Hülegü Khan : Envoys and Diplomacy in His Invasion of the Middle East, 1255-1262" ", Abstracta Iranica [En ligne], Volume 42-43 | 2021, document 46, mis en ligne le 30 décembre 2021, consulté le 18 décembre 2022. URL : http://journals.openedition.org/ abstractairanica/53889; DOI : https://doi.org/10.4000/abstractairanica.53889

Ce document a été généré automatiquement le 18 décembre 2022.

Tous droits réservés 


\title{
Na'ama O. Arom. "Arrowheads of Hülegü Khan : Envoys and Diplomacy in His Invasion of the Middle East, 1255-1262"
}

\author{
Simon Berger
}

\section{RÉFÉRENCE}

Na'ama O. Arom. "Arrowheads of Hülegü Khan : Envoys and Diplomacy in His Invasion of the Middle East, 1255-1262" in T. May, D. Bayarsaikhan, C. P. Atwood (eds.). New Approaches to Ilkhanid History. Leyde : Brill, 2020, p. 249-271.

1 Ouvrant son étude sur l'analogie opérée dans l'Histoire Secrète entre les envoyés (elchin) de Gengis Khan et des flèches, l'A. file la métaphore des différentes pointes de flèche tout au long de son examen serré de la correspondance diplomatique de Hülegü avec les souverains d'Orient et d'Occident, de sa campagne contre les Assassins et le calife abbasside à sa mort. Elle décèle, au-delà des différents registres selon les interlocuteurs et les buts recherchés, la persistance de l'idéologie mongole de domination universelle, y compris dans l'adresse au roi de France Louis IX, alors que cette lettre avait jusque-là été envisagée comme un infléchissement dans la diplomatie de l'Ilkhan (Jean Richard, Au-delà de la Perse et de l'Arménie. Turnhout: Brepols, 2005, p. 9-14; Denise Aigle, "The Letters of Eljigidei, Hülegü and Abaqa - Mongol Overtures or Christian Ventriloquism? ", Inner Asia, 7, 2005, p. 156). Cela implique donc qu'il existait une politique diplomatique consciente et réfléchie de la part de Hülegü, que suivaient aussi bien ses conseillers chrétiens que musulmans qui rédigeaient ses lettres, et que celle-ci reposait sur une idéologie avant tout mongole. 


\section{AUTEURS}

SIMON BERGER

Doctorant EHESS, CETOBAC, Paris 